\title{
МОРАЛЬНИЙ ІДЕАЛ ТА ПРИНЦИП ІНДИВІДУАЛІЗМУ: ЛЕГІТИМАЦІЙНІ ЗАСАДИ ЛІБЕРАЛІЗМУ
}

\begin{abstract}
М.Г. Тур
Після розпаду Радянського Союзу американський професор Френсіс Фукуяма полемічно загострено провістив про закінчення історії, що мало позначити собою остаточну перемогу ліберальної ідеології. За цих умов лібералізм висувається ним на роль раціонального ідеалу форми суспільства і держави, в межах якого вирішені всі суперечності і задоволені всі людські потреби. Історія завершилась, бо вона не має альтернативи. Людству залишається лише поширювати цю ідеологію на всі країни і регіони, щоб створити загальнолюдську державу - ліберальну демократію [8].

Проте у політичній філософії і досі не вщухають суперечки про легітимаційні засади лібералізму, на роль яких претендували різні чинники в класичному, розвинутому та сучасному його різновиді - неолібералізмі. Зокрема Д. Белл наголошує, що як політична філософія лібералізм зазнав значних втрат, будучи використаним в якості засобу легітимації необмежених вимог приватного економічного інтересу [1, с. 271]. Інший сучасний філософ К. Косторіадіс, поділяючи погляди Ф. фон Хайєка, характеризує крайній лібералізм як такий, що спирається на «ринкові механізми» чи «вільну індивідуальну ініціативу», вважаючи, що жодне з ціннісних суджень не може мати перевагу над іншими [3, с. 57$]$.

Для нашого сьогодення, з огляду на болісні процеси державотворення в Україні, досить актуальною постає потреба в дослідженні ліберальної традиції у вітчизняній соціально-філософській думці. В означеному контексті дослідження легітимаційних засад лібералізму неабиякий інтерес викликають ліберальні погляди видатного російського філософа й правознавця П.І.Новгородцева, твори якого тільки останнім часом стали доступними широким колам філософської громадськості. Не тільки
\end{abstract}

Актуальні проблеми духовності

(Відп. ред.: Я.В. Шрамко)

Кривий Ріг (2005), 309-318 
для свого часу, а й сьогодні, коли осереддя суперечок з проблем соціальної справедливості становить контроверза універсального і партикулярного інтересів, які, відповідно, репрезентують комунітаристи і ліберали, філософсько-правові ідеї Новгородцева про легітимаційну базу держави несуть у собі, як здається, гармонізуючий потенціал. В якості такої він пропонує розглядати аж ніяк не онтичний субстрат (економічну єдність чи етнічні коріння), а національну культуру, національні святині, ідеали істини, добра та краси. На місце автономної моралі він ставить теономну мораль, а на місце демократії і народовладдя - агіократію, себто владу святинь [6, с.579].

У статті ставиться за мету дослідити місце принципу індивідуалізму в системі філософсько-правових розвідок Новгородцева. У контексті принципу особистості спочатку буде окреслено концепт правової держави (I), щоб потім розкрити проблему суспільного ідеалу як легітимаційної засади соціальних інститутів (II).

\section{I.}

Дослідження принципу індивідуалізму стає своєрідним лейтмотивом головних праць Новгородцева - «Вступ до філософії права: Криза сучасної правосвідомості» та «Про суспільний ідеал». Це свідчить про його виразну прихильність до ліберальної традиції, яку репрезентували у вітчизняній філософії права I.А.Покровський, Б.А. Кістяковський та ін. Більше того, самоцінність окремої особи, індивіда набувають у нього значення легітимаційної засади, своєрідної теоретичної призми, в фокусі якої аналізуються такі важливі філософсько-правові та політичні поняття, як природне право, правова держава, демократія, суспільний ідеал. Однак у Новгородцева ми не знайдемо чіткого та однозначного тлумачення поняття особистості, хоча він виразно зазначає, що намагається тлумачити особистість конкретно, у «всій цілісності її моральних визначень» [6, с. 103]. Як синоніми для особистості ним застосовуються терміни «принцип особистості», «принцип індивідуалізму» тощо. Попри всю абстрактність вживання цього концепту, із контексту його вчення стає зрозумілим, що поняття особистості (принцип особистості) висувається в якості антитези загальному - суспільству та державі. Аналізуючи еволюцію поняття особистості в політичній філософії, починаючи з XVIII ст. він показує, що саме ідея прав особистості стає підгрунтям теорій правової держави, або безпосередньо в якості їі вихідної основи, або в поєднанні із принципом народного суверенітету. Головна особливість індивідуалістичних доктрин XVIII ст. полягала в припущенні можливості віднайти гармонію у відношенні «особистість-держава» [5, с. 167]. 
Все розмаїття соціально-філософських ідей по обгрунтуванню можливих шляхів досягнення соціальної гармонії між особистістю і державою, Новгородцев поділяє на два протилежні підходи. Перший - це підхід Руco, за яким людина повинна передати всі свої права державі, аби отримати з їі рук все не тільки збереженим, а й примноженим. За другим підходом, навпаки, держава має надати всі права людині і за цих умов із хаосу вільних зусиль індивідів утворюється найкращій суспільний устрій.

Перший підхід, що базується на тлумаченні особистості в її загальній і абстрактній основі, в родовій сутності, Новгородцев називає раціоналістичним. Проте, він висловлює сумнів у здатності адекватно розвинути ідеї індивідуалізму за допомогою соціології позитивізму чи історизму і наголошує, що «їх справжнім грунтом є ідеалізм» [5, с. 165]. Однак ні кантівський апріоризм, ні об'єктивний ідеалізм Гегеля не можуть слугувати для цього філософською основою. Ваду гегелівської філософії він вбачає в тому, що їі визначення особистості сформувалося на грунті ідей Французької революції про рівність і свободу, що співпадає і з кантівським її тлумаченням. Саме така родова сутність особистості і перебувала в гармонії з іншими визначеннями засадничих понять політичної філософії тієї епохи. Приміром, свобода розумілася як атрибут кожної особи і тому з необхідністю співпадала з рівністю. Із розуміння особистості як родової сутності (людина не індивідуальна, а така, що повсюди має однакову сутність, однакові потреби) випливало переконання, що достатньо віднайти загальну волю і вона відразу постане прийнятною для усіх як загальний закон співжиття.

Філософія права Гегеля, на думку Новгородцева - це лише переклад «Суспільного договору» на мову німецького абсолютного ідеалізму [5, c. 178]. У Гегеля особистість поглинається загальною моральною субстанцією, яку репрезентують закони і державні заклади. Останні тлумачилися ним як вищий розум історії, а держава - «земним богом». Хоча Гегель і розглядав свободу в якості мети і завдання історичного розвитку, проте втілення її він бачив не в окремих індивідах, які щоразу міняються, а в державних формах, які вічні. 3 гегелівського розуміння особистості виростає тлумачення індивіда у вченнях Фейєрбаха, Маркса і Ласаля. Всі вони також в якості вихідного пункту своїх соціальних концепцій обирають особистість не саму по собі, а в її родовій сутності. При такому підході щастя і свобода обіцяються людині за умови, коли вона відмовляється від самої себе і розчиняється в суспільстві [5, с. 180].

Другий підхід тлумачення поняття особистості базується на вченнях англійського і французького неолібералізму. Новгородцев доводить, що спроба Б.Констана, А.Токвіля, В.фон Гумбольда та Дж.Ст. Мілля, які розвинули ідею індивідуалізму із поняття свободи, також приводить до кризи. Так, спочатку Токвіль, а потім Міль в трактаті «Про свободу» ді- 
стали висновку, що рівність і свобода можуть суперечити один одному. Розглядаючи розвиток індивідуалізму як вищу мету людства і головну умову прогресу, вони побачили загрозу цьому в демократичних формах, які виявляють прагнення людей до рівності, уподібнення їх один одному принаймні як політичних суб'єктів. Отже, індивідуалізм, послідовно розвинутий в площині свободи, не веде до досягнення гармонії у відношенні особистість-держава.

Однак, з іншого боку, не меншу ознаку кризи індивідуалізму Новгородцев вбачає в виведенні цього поняття із поняття рівності. Рівність як і свобода випливають із поняття особистості як абсолютної цінності, що має безумовну моральну значущість [5, с. 204]. Коли в ім'я цього безумовного значення для людини вимагається свобода і водночас цю вищу моральну сутність повинні визнати за кожною людиною, то виходить, що ми вимагаємо рівності у ставленні до всіх людей. Якщо класичний лібералізм (А. Сміт, І. Бентам) виходив із негативного розуміння свободи, тобто свободи як рівності всіх перед законом, то новий лібералізм приходить вже до позитивного її тлумачення, свободи як рівності можливостей, зрівняння соціальних умов життя.

Таким чином, відзначає Новгородцев, старий індивідуалізм (класичний лібералізм) розумів завдання правової держави чітко і просто: забезпечити рівність і свободу громадян, які поставали засадами справедливого соціального ладу. Оскільки вони були вимогами цілком формальними і заперечними, то задовольнити ним було не так вже важко. Проте коли завданням держави постає наповнення цих засад новим позитивним змістом, тоді воно значно ускладнюється. Неолібералізм намагається поширити принцип рівності у бік зрівняння соціальних умов життя. Це відкриває для правової держави новий ступінь її розвитку.

У кризі індивідуалістичних доктрин Новгородцев побачив кризу тогочасної правосвідомості, сутність останньої лапідарно виражає теза: віра в непереможну силу правових начал, в їх здатність встановити на землі світлу царину розуму віджила свій вік. Право само по собі нездатне здійснити повне перетворення суспільства, а правова держава не є вінцем історії, не є граничним ідеалом морального життя. Його слід розглядати лише як підвладний засіб, що входить в якості окремого елементу в більш загальний склад моральних сил [5, с. 20].

Вихід із кризи Новгородцев вбачає в тому, щоб розглядати правову держави як регулятивну ідею в кантівському розумінні. Криза зникає, коли конечність вдосконалення держави заступає початок безкінечного її вдосконалення. Завдяки цій заміні тимчасові історичні ідеали втрачають абсолютний характер. Саме в цій перспективі здатні отримати своє справжнє виправдання історичні шляхи правової держави, як регулятивної ідеї, що відкриває простір для вияву всіх життєвих можливостей. Звідси крах 
віри в досконалу правову державу постає лише крахом утопічного бачення їі сутності.

Головний недолік як першого так і другого підходів гармонізації відношення «особистість-суспільство», на думку Новгородщева, полягає в схематизмі, спрощенні дійсних соціальних відношень, що є наслідком досить поверхового аналізу поняття особистості, їі мети та засобів. Ці теоретичні спрощення в обох випадках неодмінно призводили і до спрощення проекцій розв'язання практичних проблем. Класичний індивідуалізм, що обіцяв невдовзі світлу та щасливу перспективу, зазнав краху. Неоліберальні вчення, що прийшли йому на зміну, накреслили не гармонію майбутнього блаженства, а шлях поступового вдосконалення, шлях складних зусиль, який за самою своєю природою є нескінченним. Проте, засадничий індивідуалістичний принцип - принцип особистості- залишається незмінним. Водночас, відзначає Новгородцев, конкретні вимоги, які в наш час імплікуються із принципу особистості, надзвичайно ускладнилися. Держава виявила свою неспроможність задовольнити ці вимоги не тільки негайно, а й у передбачуваному майбутньому. Якщо класичний лібералізм свої надії покладав на виправлення держави та державних установ, то неоліберальні теорії, передусім французькі, збагатили, на думку Новгородцева, доктрину індивідуалізму принципом солідарності, усвідомленням того, що правові установи самі по собі не здатні забезпечити посправжньому глибоке оновлення суспільного життя; вони повинні для досягнення своєї мети відчути опору в силах моральних.

Отже, в ідейних межах самого лібералізму відбулася значна еволюція поглядів на державу. Від поняття держави «земного бога», яке було поширеним в часи панування ідеї права, коли держава розглядалася в якості визначного чинника в справі морального прогресу, політичний досвід XIX ст. привів до усвідомлення, що в справі успішного здійснення своїх завдань, держава має покладатися на допомогу морального чинника. Це засвідчило початок нового етапу в розвитку правової держави, на якому здійснюється перехід від засад «формальних» і «заперечних» до основ «позитивних», коли держава бере на себе шляхетну місію служіння суспільству. Цим висновком Новгородцев не тільки збагатив традиційні філософсько-правові погляди російських мислителів того часу, а й суттєво доповнив західну політичну філософію тим, що наголосив на необхідності пошуку нових реформ, завдань і цілей правової держави. У нього імпліцитно йшлося про ідею соціальної держави як вищої форми правової держави.

Ці положення отримали грунтовну розробку в філософії права пізніше, у XX ст. Як зазначає провідний дослідник сучасної правової держави Ю. Хабермас, проект соціальної держави більш-менш успішно вдалося здійснити в Західній Європі тільки після другої світової війни. Він дохо- 
дить на перший погляд парадоксального висновку про те, що «правова держава і соціальна держава можливі в принципі і без демократії» $[9$, с.647], оскільки тільки політичні права на участь обгрунтовують рефлексивне, самореферентне правове становище громадянина, тоді як негативні права на свободу і соціальні пайові права можуть поставати у вигляді патерналістського дарунку. Пояснюючи цю тезу, німецький філософ зазначає далі, що ліберальні права, розглянуті в історичній перспективі, кристалізувалися навколо соціального статусу приватного власника. У функціональному плані їх можна визначити як інституціоналізацію ринкової економіки, тоді як в нормативній площині вони гарантують індивідуальні свободи. Щодо соціальних прав, то в функціональному плані він тлумачить їх як сферу формування бюрократії добробуту, а в нормативному - як такі, що покликані постати основою справедливого державного устрою, побудованого на засадах позитивного права [9, с. 648].

Новий французький лібералізм збагатив доктрину лібералізму новим принципом солідарності, який наголошує на наявності в особистості не тільки прав, а й обов'язків. У цьому випадку особистість розглядається в новому ракурсі. Оскільки вона встановлює стосунки з іншими індивідами, то, з одного боку, вона має усвідомлювати свої права, виступає з вимогами своєї свободи і рівності, а з іншого - обов'язків, бо ці права в суспільстві закріплюються шляхом їх обопільного визнання. Новгородцев вважає, що принцип солідарності зрештою привів пошуки політичної думки до відродження ідеї соціального виховання, яка була висунута ще античними філософами. Однак і в системі виховання має повторитися боротьба індивідуалістичного і зрівняльного первенів, яка притаманна всьому ходу культури.

На тверде переконання Новгородцева, доповнення принципу індивідуальності концепцією солідарності робить можливим уникнути крайнощів абсолютного індивідуалізму, який проголошує особистісне начало початком і кінцем моральних прагнень. Така позиція заводить у глухий кут знеособлення особистості, приводить до суб'єктивного свавілля і спустошення особистості, позбавляє їі опори в світі. Усвідомлення необхідності солідарності суспільства, нерозривного зв'язку всіх людей на засадах їх взаємних обов'язків виявляє прагнення до загального і надіндивідуального, відкриває зв'язок окремих індивідів між собою, що утворює підгрунтя для суспільного ідеалу.

II.

Нерідко поняття правової держави подається як правовий ідеал, який $є$ видовим поняттям родового поняття «суспільний ідеал». Дослідженню феномена ідеального суспільства Новгородцев присвятив свою головну 
працю «Про суспільний ідеал». Препаруючи утопію земного раю, він відзначає, що вона спрямована на те, щоб дати людині «безумовне задоволення», повну гармонію життя, яка складається із надання їй умиротворення, духовного ладу, самоідентифікації, врятування від спокус та гріхів світу. I в цьому розумінні кожний суспільний ідеал, який явно чи неявно спирається на ідею земного раю, по суті постає відтворенням середньовічної теократії, яка проповідувала рятування людей засобами віри. Зримі контури цього Новгородцев знаходить і у Русо в його проекті громадянської релігії, і у Гегеля в ідеї божественної держави, і у Конта в площині рятування людства на засадах позитивізму, і у Маркса в його принципі абсолютної емансипації людини [6, с. 42].

Витлумачена у такий спосіб проблема суспільного ідеалу зливається з релігійною проблемою рятування людства, а досконале суспільство набуває смислу вищої моральної цінності, яка надає людині як повноту буття, так і сенс її існування. Суспільний первень набуває щодо людини абсолютного характеру. Відданість йому має заступити релігійне почуття, поклоніння сакральному. Аргументацію цієї тези Новгородцев розгортає на основі аналізу соціального вчення Маркса, переконливо показуючи, водночас, чому воно з необхідністю повинне було постати войовничим атеїзмом. Так, у «Критиці гегелівської філософії права» релігія тлумачиться Марксом як спотворене усвідомлення світу, як самосвідомість людини, яка або ще не знайшла, або вже втратила саму себе. Маркс доходить висновку про те, що релігію породжує суспільство, держава, оскільки вони самі являють собою перекручений світ. Звідси боротьбу проти релігії, що пропонує ілюзорне щастя, марксизм розглядає як боротьбу проти того світу, породженням якого вона є. Отже, боротьба з релігією для Маркса постає символом боротьби з суспільною несправедливістю, з практикою і політикою політичного гноблення і деспотизму і таким чином «критика неба перетворюється в критику землі, критика релігії-у критику права, критика теології в - критику політики» $[4$, с. 385].

Існування релігії Маркс пояснює недовершеністю теперішнього суспільного життя, державного устрою, зіпсованістю людини суспільством, в якому вона відчужена від своєї родової сутності. Тому невипадково, що врятування людини він вбачає в площині злиття $\dddot{1}$ з родом, суспільним началом. Сутність людини розчиняється ним в сукупності суспільних відносин. Релігія тлумачиться як опій народу, як примарна ілюзія, що відволікає людину від справжнього буття. Якщо вона шкідлива у недосконалому суспільстві, то тим більш для неї не повинно бути місця в досконалому суспільстві, яким малюється соціалізм. I справді, чи буде таке суспільство ідеальним, яке неспроможне дати повного щастя людині, бо для задоволення певних духовних потреб вона змушена звертатися до релігії. Отож, висновує Новгородцев, все зводиться до того, щоб знайти 
форму суспільного устрою, за яким людина відчула б себе в гармонійній єдності з суспільним оточенням. Але такий хід думки веде до припущення можливості існування в принципі повної гармонії між особистістю і суспільством. Новгородцев зазначає, що пошук такої гармонії постає незмінним грунтом усіх соціальних утопій. Якщо XVIII століття подарувало особистості декларацію невідчужуваних прав, то XIX збагатило її усвідомленням своєї неповторної індивідуальності. Разом з тим, з XIX ст. особистість винесла відчуття незадоволеної туги, жадобу вищого ідеалу, думку про своє протистояння суспільству.

Сьогодні, на початку третього тисячоліття не втратив своєї актуальності висновок філософа про те, що жоден суспільний інститут не повинен відігравати для людини за роль абсолютної мети. Вони мають розглядатися лише в якості необхідних і незамінних засобів на шляху просування до морального прогресу [6, с.44]. Навпаки, вищою моральною цінністю проголошується сама людина, в площині якої отримують легітимацію форми соціально-державного устрою. Тому віра в земний рай, який $€$ по суті недосяжним, має поступитися вірі в людську дію і моральне зобов'язання, вірі в абсолютний ідеал добра, із якого людина живиться в своєму неухильному моральному прагненні. У дусі неокантіанців моральний обов'язок, витлумачений в якості регулятивної ідеї, постає завданням морального прогресу, постійного шляху моральних пошуків і прагнень. У цій площині суспільний ідеал - як земний рай - перетлумачується ним як безперервна праця, обов'язок постійного прагнення до мети, що постійно ускладнюється, що саме і складає суть суспільного прогресу [3, с.47].

Заперечуючи гармонію майбутнього людства, для якого минуле і сьогодення - це лише підмостки і ліса, Новгородцев пропонує розглядати в якості ідеального первня соціальності безумовне моральне значення особистості в кожній історично обумовленій формі соціальності. Адже, якщо припустити домінування суспільної єдності над особистістю, то це неодмінно призведе до перетворення її в засіб і знаряддя для майбутнього блаженства невідомо яких істот, які, до речи, ніколи не з'являться, оскільки сама ідея досягнення суспільного ідеалу є утопічною.

Отже, на тверде переконання Новгородцева, проблема індивідуальності вкорінена не в культурному чи суспільному проявах особистості, а в глибинах її власної свідомості, в її моральних та релігійних потребах. Більш того, на рівні природного інстинкту людині притаманна властивість прагнути до нерівності і не тільки стосовно інших, а й в межах власного існування, тобто як духовне зростання, як вдосконалення себе. Він виголошує впевненість, що придушити цей сутнісний вияв особистості, що «живить людську душу» не спроможна жодна форма громадськості [5, с. 199]. На цьому ідейному грунті філософ пророкував крах соціалістичного експерименту більшовизму. 
Виникнення суспільного ідеалу неодмінно пов'язується з вірою в чудо загального перетворення. Так, аналізуючи доктрину Русо про народний суверенітет, Новгородцев відзначає, що прибічники Русо у XVIII ст. мріяли про настання царини правди та добра. Вони сповіщали про «чудеса республіки». Маркс і Енгельс в XIX ст. говорячи про «стрибок із царини необхідності в царину свободи» непомітно для себе також висловлювали думку про перехід в інший світ, в якому весь уклад життя буде іншим. Проте ці соціальні вчення нагадують есхатологічні вчення про майбутнє. Попри величезні розбіжності в тлумаченні абсолютного блаженства, перехід до нього тут і там подається як розрив історичного процесу, як стрибок в інший світ, що знаходиться за межами усталених відносин. Заперечуючи фіналістську філософію історії, Новгородцев відстоює думку про нескінченість суспільного прогресу, «про відсутність логічного кінця у часовому прогресі відносних форм» [6, с. 61]. Майбутня гармонія суспільного ідеалу в такому разі постає ілюзією, бо справжню реальність становить вічний ідеал добра, який вимагає визнати в історії як вищу реальність - живу людську особистість. Постулюючи за кожною людською особистістю безумовне моральне значення, він виводить із цієї тези мету і критерій суспільного прогресу: «... метою і критерієм прогресу має розглядатися поняття особистості» [6, с.67].

У такий спосіб Новгородцев доходить важливого висновку про те, що соціальна філософія має обгрунтовувати свої теоретичні конструкції не у відповідності з тимчасовою гармонією майбутнього ідеального соціального устрою, який має здійснитися в кінці історії, а у відповідності з вічною гармонією абсолютного ідеалу добра, яка однаковою мірою підноситься i над початком, i над кінцем, і над всією історією. Саме ідеал добра, а не ідея соціальної гармонії, втіленням якої постає суспільний ідеал, буде обов'язковим для кожного етапу історії, кожної генерації, кожної людини. Що стосується суспільного ідеалу, то в цій площині він здобуває вже ознак регулятивної ідеї і тлумачиться як безкінечний шлях морального прогресу, що з необхідністю заперечує конечність історії.

Новітня політична історія XX століття надає достатньо переконливих прикладів облудності проекцій соціальних ідеалів, які породжували зразки тоталітарного мислення i, як наслідок, тоталітарні форми соціального устрою. Застереженням мають звучати слова Ф.Гєльдерліна, який казав: «Що завжди перетворювало державу у пекло на землі, так це спроба людини зробити її земним раєм» (Цит. за $[2$, с. 7]). У цьому ж ключі висловлюється сьогодні фундатор теорії трансцендентальної прагматики K.-О.Апель: гегелівська спіраль історії має бути незамкненою, бо ідеал здатний перетворитися в утопію, яка з необхідністю веде до «диктатури ідеалу» і тоталітаризму [7, с. 147].

Насамкінець відзначимо, що дослідження ідеї суспільного та правово- 
го ідеалу як легітимаційних засад суспільного розвитку і сьогодні не втратило свого значення. Ідеал суспільно-правового устрою виконує спрямовуючу і регулятивну роль у справі розбудови сучасної української держави та інших держав, що утворилися на теренах колишнього Радянського союзу.

\section{1 Бібліографія}

[1] Белл Деніел. Культурні суперечності капіталізму // Сучасна зарубіжна соціальна філософія. Хрестоматія: Навч. Посібник / Упоряд. Віталій Лях. - К.: Либідь, 1996. - С. 251-274.

[2] Ивин A.A. Введение в философию истории.-М.: Гуманит. изд. центр ВЛАДОС, 1997.

[3] Косторіадіс Корнеліус. Демократія як процедура і як режим // Політика та етика. - К.: Укр. філос. фонд, 1999. - С.46-68.

[4] Маркс K. До критики гегелівської філософії права: Вступ // К. Маркс і Ф. Енгельс. Твори у 50 т. - Київ, 1958. - Т. 1. - С. 384-397.

[5] Новгородцев П.И. Введение в философию права: Кризис современного правосознания. - М., 1996.

[6] Новгородиев П.И. Об общественном идеале.-М.: Пресса, 1991.

[7] Назарчук A.В. Этика глобализирующегося общества.-М.: Директмедиа Паблишинг, 2002.

[8] Фукулма Ф. Конец истории? // Вопросы философии. - 1990. - №3. C. $134-148$.

[9] Habermas J. Faktizität und Geltung. Beiträge zur Diskurstheorie der Recht und des demokratischen Rechtsstaates. - Frankfurt a. M., 1992. 